\title{
KARAKTERISTIK SPASIAL PERMUKIMAN VERNAKULAR PERAIRAN DI SULAWESI TENGAH \\ (Characteristic Settlement on The Spatial of Aquatic Vernacular at Central Sulawesi)
}

\author{
Ahda Mulyati*, Nindyo Soewarno, Arya Ronald dan Ahmad Sarwadi \\ Jurusan Arsitektur dan Perencanaan Fakultas Teknik, Universitas Gadjah Mada, \\ Jl. Grafika no. 2 Kampus UGM, Yogyakarta 55281.
}

*Penulis korespondensi. Tel/Fax: 0274-631179/589659. Email: ahdamulyati@gmail.com.

Diterima: 26 Mei 2015

Disetujui: 15 September 2015

\begin{abstract}
Abstrak
Permukiman masyarakat perairan terbentuk karena kondisi alam dan geografi yang rentan terhadap bencana. Masyarakat setempat membangun rumah tinggal berbentuk panggung, di mana sebagian atau seluruhnya berada di atas air, menggunakan bahan bangunan yang mudah diperoleh di lingkungannya. Tujuan penelitian untuk mendapatkan gambaran karakteristik spasial permukiman vernakular perairan khususnya di Sulawesi Tengah. Penelitian menggunakan metode studi kasus dengan pendekatan kualitatif, pengambilan data dilakukan secara naturalistik dan teknik analisis secara induktif. Awalnya permukiman dibentuk oleh pemukim karena kebutuhan tempat bernaung dan berlindung. Tempat dipilih yang dapat memberi keamanan bersama keluarga, sehingga pulau-pulau karang menjadi pilihannya. Kelompok terdiri atas beberapa keluarga, membangun tempat tinggal mengelilingi daratan bukit karang sesuai pengetahuan lokalnya. Dalam perkembangannya, jumlah permukim bertambah, sehingga unit-unit permukiman tumbuh dan berkembang ke laut. Permukiman terdiri atas deretan rumah tinggal dihubungkan oleh jalan atau jembatan kayu (tetean). Unit-unit permukiman membentuk spasial di mana rumah tinggal mengelilingi ruang-ruang publik. Interaksi sosial dilakukan pada dego-dego, jalan setapak (tetean) dan ruang-ruang publik permukiman. Interaksi lain biasanya dilakukan pada saat melaut mencari ikan. Laut sebagai akses antar unit-unit lingkungan, tempat bermain bagi anak-anak dan ruang kehidupan bagi pemukim. Rumah tinggal merupakan ruang privat, sedang dego-dego, tetean jalan dan pasar adalah ruang publik. Spasial permukiman membentuk pola melingkar satu arah mengelilingi daratan bukit karang atau linier satu dan dua arah. Orientasi lain dan bersifat privat yaitu laut sehingga ruang belakang rumah tinggal (tatambe) menghadap ke laut. Pusat permukiman adalah mesjid sebagai ruang sakral sekaligus ruang publik.
\end{abstract}

Kata kunci: karakteristik, perairan, permukiman, spasial, vernacular.

\begin{abstract}
Community settlements waters formed due to natural and geographical conditions that are vulnerable to disasters. They have built houses, where the majority or entirely are above of water, using the building materials which are easy to obtain at the environment. This research purposes to get an idea of the spatial characteristics of the vernacular waters of settlements, especially at Central Sulawesi. This research use case study method with qualitative approach and data were collectend with naturalistic and analysis technique was inductive. The settlements of aquatic community were formed because of natural conditions and geography condition that are particularly vulnerable to disasters. At first, the settlements were established by the settlers because of the need for shelter and refuge. They chosed a shelter that can provide security with his family, so that the islands adjacent to the place that gives life is the choice. A group of several families eventually built their houses around the inland cliffs appropriate to their local knowledge. In the development of settlers grew, the settlement units grow and develop over the sea. Also the houses made a linear line form around the coral reef. The settlement consists of a row of houses (very dense on the mainland island) which are connected by a road or bridge timber (tetean). These units settlement form a spatial between the houses around public spaces that are streets, mosques, schools, village halls, shops, washing bath, and places to play. Social interaction settlers were carried on the front porch, pathways, and public spaces in neighborhoods. Another interaction is usually done when they are fishing. The sea also serves as an access between the units and a playground for neighborhood children as well as space for the life of settlers. The residential house is a private space but the front porch and the road is public space. The spatial of settlement forms a circular pattern around the land of the cliff, or a linear one-and two-way and the street or tetean serves as the access and public space which is as the central orientation. The other orientation as private spaces is 'the sea' so that behind of the houses face the sea. The central of settlement is the mosque or mushollah which has function as sacred space and public space.
\end{abstract}

Keywords: characteristic, spatial, settlement, vernacular, aquatic. 


\section{PENDAHULUAN}

Sulawesi Tengah mempunyai garis pantai terpanjang di Sulawesi sehingga sebagian besar masyarakatnya bermukim di wilayah pesisir. Ruangruang pesisir hampir terdapat pada semua wilayah, sehingga berkembang masyarakat pesisir yang mendiami kawasan pesisir dan pulau-pulau. Masyarakat tersebut mempunyai mata pencaharian sebagai nelayan sehingga membangun rumah tinggal dan permukimannya pada kawasan di mana mereka dapat menyatu dan hidup dengan tempat yang memberinya kehidupan. Pada umumnya permukiman tidak direncanakan dengan baik, spontan, hanya sebagai tempat tinggal bagi keluarganya jika mereka pergi melaut. Permukiman dibangun sesuai tingkat pengetahuan lokal mereka, tidak mengenal standar atau norma-norma yang baku, hanya sesuai kebutuhan pada masa itu.

Masyarakat berkembang sesuai budaya lokal yang dimiliki sebagai ciri khas dan spesifik dalam mengatur kehidupan mereka. Kebiasaan-kebiasaan inilah yang berkembang menjadi hukum adat yang mengatur berbagai aspek kehidupan baik dalam hubungan sosial kemasyarakatan, ritual, kepercayaan, dan lain-lain. Hal-hal tersebut tercermin dalam wujud kehidupan mereka, baik pada lingkungan fisik maupun lingkungan sosial masyarakat sebagai karakter, keunikan dan citra budaya yang khas pada permukimannya. Keunikan pada lingkungan sosial maupun lingkungan fisik menjadi daya tarik dan dikembangkan sebagai nilai lokal dari pemukiman itu (Hamundu dan Manan, 2004).

Vernakular adalah bahasa setempat, istilah ini untuk menyebut bentuk-bentuk yang menerapkan unsur-unsur budaya, lingkungan termasuk iklim setempat, diungkapkan dalam bentuk fisik arsitektural (tata letak, denah, struktur, detail-detail, ornamen, dan lain-lain). Tempat tinggal dan semua bangunan publik terkait erat dengan konteks lingkungan. Mereka atau masyarakat membangun masih memanfaatkan teknologi tradisional. Semua bangunan berbentuk arsitektur vernakular yang spesifik, mengandung nilai-nilai, kondisi ekonomi dan kehidupan budaya masyarakatnya (Oliver, 2006).

Arsitektur vernakular sering disebut arsitektur kerakyatan, menunjukkan sesuatu yang asli, etnik, dan tradisional. Arsitektur vernakular sering disebut arsitektur adat, arsitektur informal, arsitektur spontan, arsitektur rakyat atau arsitektur tradisional. Cerminan arsitektur vernakular dapat dilihat pada dialog manusia dengan lingkungan, tanggap terhadap lingkungan, keterbatasan material, budaya dan teknologi serta dalam konteks relasi sosial. Keberadaan bangunan atau lingkungan selalu terlingkupi faktor lingkungan fisik dan sosialbudaya karena lahir di dalam jejaring kehidupan manusia (Mentayani, dan Ikaputra, 2012).

Secara umum arsitektur vernakular memiliki karakteristik antara lain, dibuat tanpa bantuan tenaga ahli, mampu beradaptasi terhadap kondisi fisik, sosial, budaya, religi, teknologi dan material setempat, dibangun untuk mewadahi kebutuhan masyarakat dan mengakomodasi nilai-nilai budaya masyarakat, ekonomi dan cara hidup masyarakat setempat. Selain itu fungsi, makna dan tampilannya dipengaruhi oleh aspek struktur sosial, sistem kepercayaan dan pola perilaku masyarakatnya

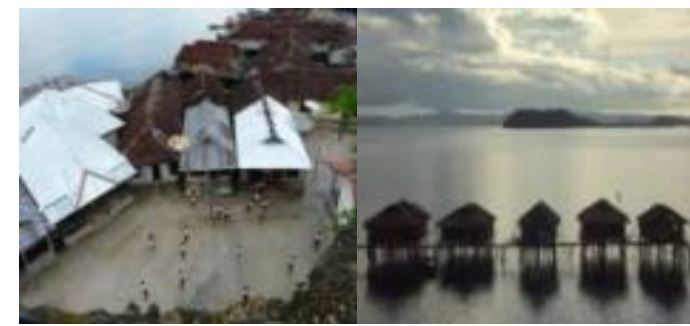

$\mathrm{a}$

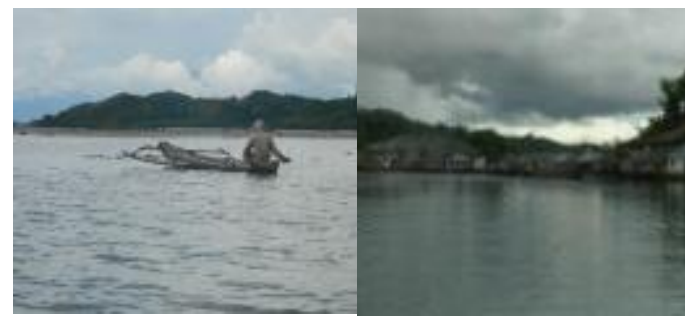

e

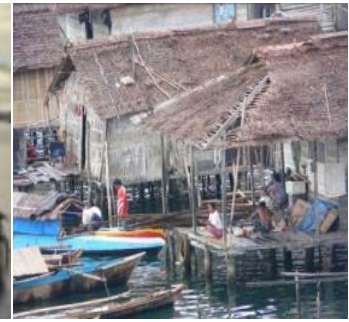

C

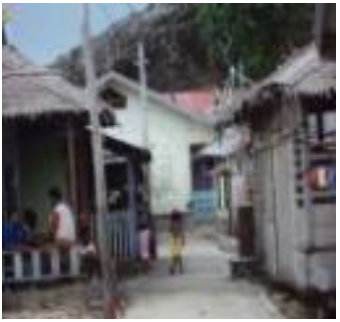

d

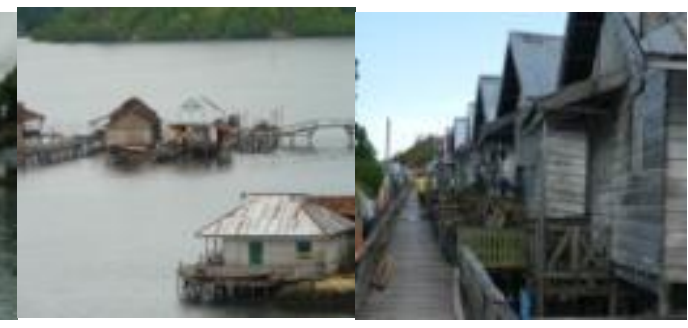

g

Gambar 1. Kondisi permukiman perairan di Sulawesi Tengah. (a) ruang publik, (b) unit rumah tinggal di air, (c) tatambe (ruang belakang rumah) (d) lalan (jalan daratan mengelilingi bukit karang), (e) pemukim sebagai nelayan, (f) permukiman dari arah depan, (g) unit permukiman dan (h) tetean (jembatan kayu)

(Sumber : Data lapangan, 2010-2011) 
.Secara umum, permukiman vernakular mempertimbangkan kondisi-kondisi fisik yang melingkupinya selain unsur-unsur sosial-ekonomibudaya-religi berpengaruh terhadap karakteristiknya, dan aspek yang sangat kuat berpengaruh yaitu lingkungan budaya. Struktur sosial mempengaruhi karakter khusus pada hunian, permukiman dan desa. Begitu pula tradisi ritual suatu masyarakat mempengaruhi organisasi spasial sebuah desa, sedang tradisi perkawinan, dan tradisitradisi lain, berpengaruh pada tata letak dan pengembangan desa suatu masyarakat. Oliver (2006) mengemukakan bahwa ciri spesifik pada sosio-budaya masyarakat akan menghasilkan arsitektur vernakular baik pada bangunan, permukiman dan desa.

Lingkungan terbangun oleh hubungan dari relasi-relasi elemen didalamnya dan memiliki pola dan struktur tertentu. Relasi yang terbentuk antara manusia dengan lingkungan fisik secara fundamental bersifat spasial, dipisahkan dan disatukan di dalam dan oleh ruang (Doxiadis, 1957). Oleh karena itu, karakteristik, sosial dan budaya suatu lingkungan tercermin dalam tatanan spasialnya. Ruang merupakan ruang tiga dimensional yang mengelilingi manusia, relasi antara elemen-elemen didalamnya membentuk tatanan tertentu disebut organisasi spasial (Setioko, dkk, 2011). Aspek spasial merupakan unsur pada tatanan ruang, karena space (ruang) adalah aspek permukaan, sedang spasial mencakup struktur didalamnya, dan mencerminkan karakteristik space (Hiller, 1984). Ruang selalu terkait dengan manusia dan kehidupannya, dimana manusia terhadap artefak-artefak membentuk 'spasial budaya'. Spasial budaya adalah tatanan ruang tertentu yang mengungkapkan tatanan relasi artefak-artefak berdasarkan prinsip tatanan sosial. Relasi bolak balik antara tatanan sosial dengan tatanan fisik spasial, mencerminkan bahwa pada momen tertentu tatanan spasial dipengaruhi oleh tatanan sosial, begitu pula sebaliknya.

Struktur spasial permukiman tradisional dapat dikatagorisasikan ke dalam dua hubungan yang mendasar, yaitu pertama global space dengan elemen space dan yang kedua adalah hubungan antara elemen-elemen space itu sendiri. Ada dua hubungan mendasar diwujudkan dalam 4 (empat) konsep struktur spasial yaitu placement dan sequence sebagai hubungan antara global space dengan element space sedangkan interaction dan hierarchy sebagai hubungan antar element space. Global space didasarkan atas kognisi penduduk desa, sedang tanah, jalan, unit-unit rumah, fasilitas lingkungan merupakan element spaces (Han, 1991).

Manusia sangat menentukan dan mencerminkan keunikan suatu permukiman, khususnya pada arsitektur permukiman vernakular. Keunikan akan terlihat pada cara manusia berperilaku terhadap lingkungan yang menjadi ruang kehidupan manusia (Madanipour, 1996). Perilaku me-ruang manusia mempunyai sistem tertentu, dan berpengaruh terhadap tatanan spasial yang terbentuk sebagai wadah kehidupannya (Waterson, 1990). Perbedaan individu, kelompok dan masyarakat menghasilkan konsep dan wujud ruang yang berbeda (Rapoport, 1969; Haryadi dan Setiawan, 2006; Rejeki dkk., 2008). Bentukan lingkungan merupakan hasil pikiran dan perilaku manusia. Setiap kelompok etnis memiliki image yang khas tentang lingkungannya, karena perilaku masing-masing etnis juga khas. Bentukan lingkungan tidak hanya disebabkan kondisi iklim dan lingkungan yang unik, tetapi juga perilaku dari etnis itu sendiri. Berdasarkan isu-isu tersebut, maka karakteristik spasial permukiman vernakular perairan perlu diuji, khususnya di Sulawesi Tengah kaitannya dengan perilaku pemukim terhadap kondisi lingkungan permukimannya.

Tujuan penelitian ini mengetahui karakteristik spasial permukiman vernakular perairan khususnya di Sulawesi Tengah. Hasil penelitian diharapkan dapat memberikan tambahan wawasan kepada pemerintah daerah dan akademisi tentang adanya karakter ruang yang spesifik terkait dengan kondisi alam dan lingkungan pada kawasan tersebut. Selain itu bagi masyarakat/pemukim setempat diharapkan dapat memberikan pengetahuan tentang spasial permukimannya baik peruntukan ruang bermukim, ruang mata pencaharian dan ruang-ruang sosial, sehingga diharapkan dapat memanfaatkan ruangruang sesuai kebutuhannya.

\section{METODE PENELITIAN}

Penelitian menggunakan metode studi kasus untuk melihat fenomena dalam konteks sekarang, khususnya ketika batas antar fenomena dan konteks obyek tidak memiliki batas yang jelas (Yin, 2003) karena pendekatan studi kasus tidak hanya menggali karakteristik tetapi juga sebab-akibat dari obyek yang diteliti (Yin, 2003). Paradigma penelitian adalah kualitatif, pengumpulan data secara naturalistik dan teknik analisis secara induktif. Teori-teori arsitektur dan morfologi permukiman sebagai konsep normatif menjadi landasan didalam melakukan penelitian dan membangun kisi-kisi penelitian.

Pengumpulan data menggunakan metoda observasi lapangan, wawancara, dokumen dan artefak fisik yaitu permukiman pesisir yang menjadi lokus penelitian. Wawancara dan observasi digunakan untuk mendapatkan data primer tentang kondisi dan potensi lokus penelitian. Data-data 
diperoleh melalui wawancara mendalam pada masyarakat yang bermukim atau yang mengetahui sejarah terbentuknya permukiman pesisir dan pulaupulau. Oleh sebab itu kajian ini menggunakan berbagai kepustakaan untuk mengetahui konsep terbentuknya spasial permukiman. Pengumpulan dokumen untuk mendapatkan data tentang kebijakan pembangunan permukiman perairan. Teknik analisis yaitu membangun penjelasan naratif (explanation building) sehingga dapat menggambarkan spasial permukiman vernakular perairan di Sulawesi Tengah. Lokus yang menjadi amatan adalah permukiman pulau-pulau dan pesisir yang tersebar di Sulawesi Tengah yaitu pulau Kabalutan, pulau Sambujan, Labuhan Lobo dan desa Labuan.

\section{HASIL DAN PEMBAHASAN}

\section{Spasial Terkait dengan Kondisi Alam dan Lingkungan}

Permukiman masyarakat perairan terbentuk karena kondisi alam dan geografi yang sangat rentan terhadap bencana. Masyarakat membangun rumah tinggalnya berbentuk rumah panggung, di mana sebagian atau seluruhnya berada diatas air, menggunakan bahan-bahan yang mudah diperoleh di lingkungannya, yaitu kayu, bambu, daun silar, enau, dan lain-lain. Awalnya permukiman dibentuk oleh pemukim karena kebutuhan akan tempat bernanung dan berlindung. Masyarakat memilih tempat bernaung yang dapat memberi keamanan bersama keluarganya, sehingga pulau-pulau karang dan pesisir pantai yang berdekatan dengan tempat yang memberi kehidupan adalah pilihannya. Kelompok yang terdiri atas beberapa keluarga akhirnya membangun rumah tinggal sesuai pengetahuan lokalnya mengelilingi daratan bukit karang di tengah laut dan mendekati daratan pantai.

Dalam perkembangannya pemukim semakin bertambah, sehingga unit-unit permukiman tumbuh dan berkembang di laut dan sepanjang pantai.

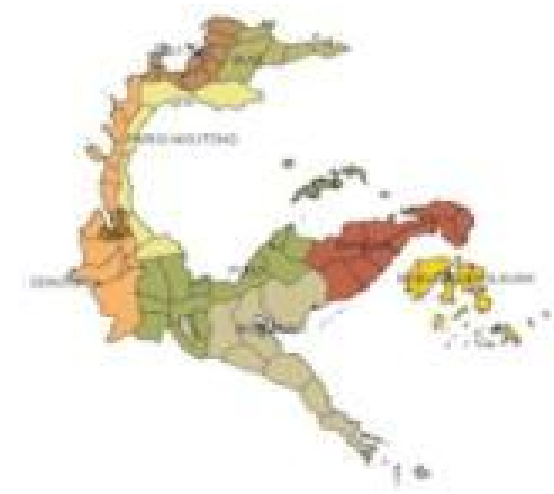

a
Kumpulan rumah tinggal ini membentuk garis linier mengelilingi bukit karang, laut dan pantai. Permukiman terdiri atas deretan rumah tinggal (sangat padat pada bagian daratan kepulauan, daratan pantai) dihubungkan oleh jalan atau jembatan kayu (tetean). Unit-unit permukiman membentuk spasial dimana rumah tinggal mengelilingi ruang-ruang publik yaitu jalan, mesjid, sekolah, balai desa, warung, tempat mandi cuci, dan tempat-tempat bermain. Laut tidak hanya sebagai ruang kehidupan tetapi juga sebagai ruang bermain dan akses antar unit-unit lingkungan bagi pemukim menggunakan sampan (leppa-leppa). Rumah tinggal merupakan ruang privat sehingga teras bagian depan dan jalan adalah ruang-ruang publik.

\section{Spasial Terkait dengan Interaksi Sosial Pemukim}

Pemukim dalam kehidupan kesehariannya akan melakukan interaksi, baik dengan pemukim itu sendiri maupun terhadap lingkungannya. Interaksi sosial umumnya dilakukan pada teras depan rumah, jalan setapak, tetean dan ruang-ruang publik yang ada di lingkungan permukiman. Keadaan ini biasanya ramai pada sore hari, anak-anak kecil bermain dan ibu-ibu mengobrol sambil mengasuh anak. Ruang-ruang lain yang dimanfaatkan sebagai ruang interaksi adalah tempat mandi cuci, yang terdapat pada unit-unit lingkungan. Interaksi terjadi pada saat warga mandi, mencuci dan mengambil air bersih untuk kebutuhan pemukim di masing-masing rumah.

Interaksi lain biasanya dilakukan pada saat warga melaut mencari ikan. Masyarakat melakukan pekerjaan secara bersama-sama baik dalam satu leppa (perahu) atau berbeda leppa (perahu). Masyarakat akan menuju tempat mencari sumber daya laut sesuai nalurinya dan petunjuk alam, sehingga akan memperoleh hasil yang memadai untuk kehidupan keluarganya. Kegiatan mencari sumber daya laut biasanya dilakukan pada siang hari dan pulang pada keesokan paginya. Keterbatasan

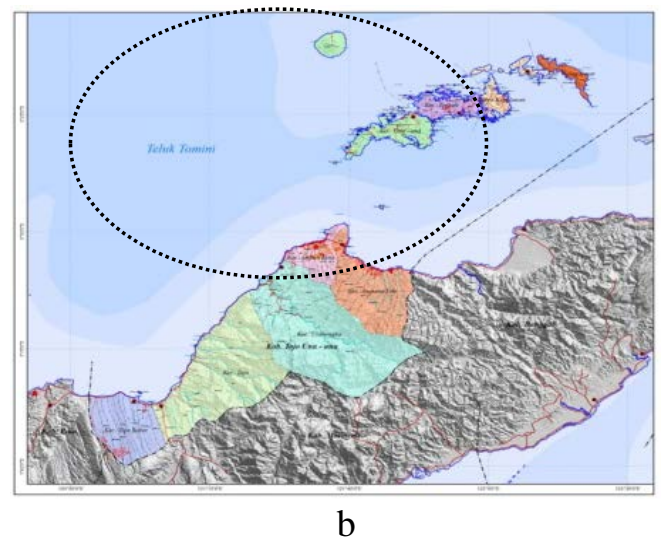

Gambar 2. Letak kasus permukiman perairan (a) Propinsi Sulawesi Tengah dan (b) Kabupaten Tojo Una-una (Sumber : Pemda Kabupaten Tojo Una-Una, 2010) 


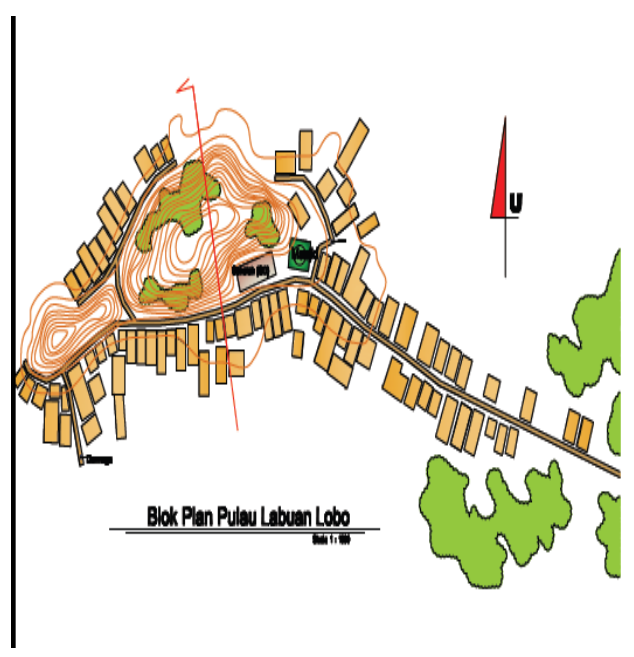

(a)

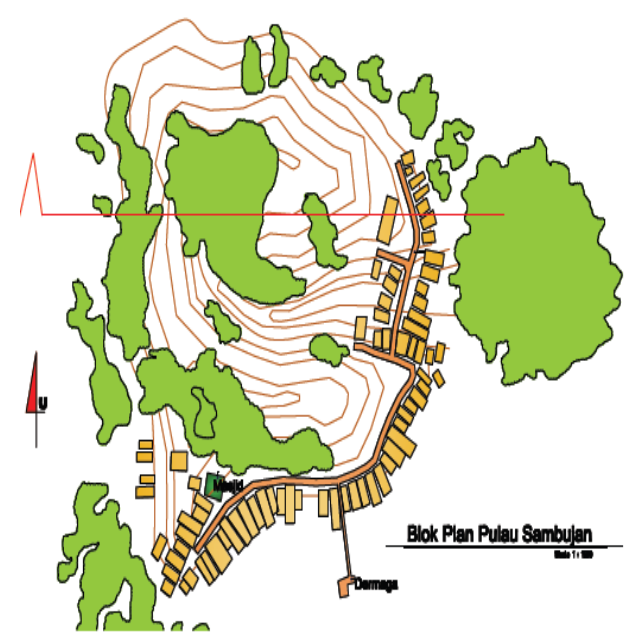

(b)

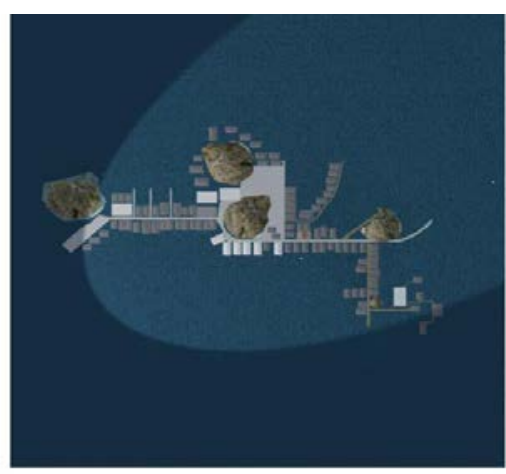

(c)

Gambar 3. Ragam bentuk permukiman masyarakat vernakular perairan. (a) Desa Labuan kabupaten Toli-toli; (b) Desa Sambujan kabupaten Toli-toli; (c) desa Kabalutan kabupaten Tojo Una-una (Sumber : Analisis induksi berdasarkan data lapangan, 2012)

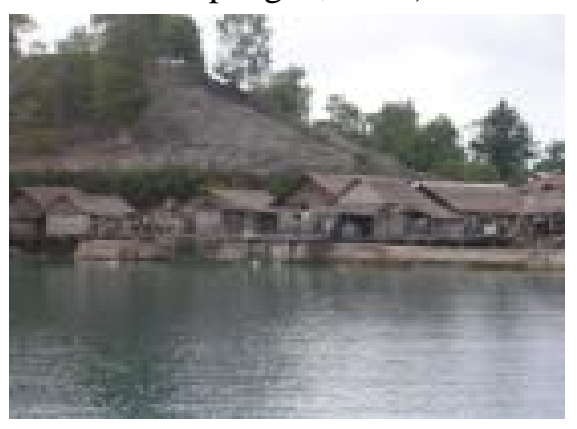

(a)

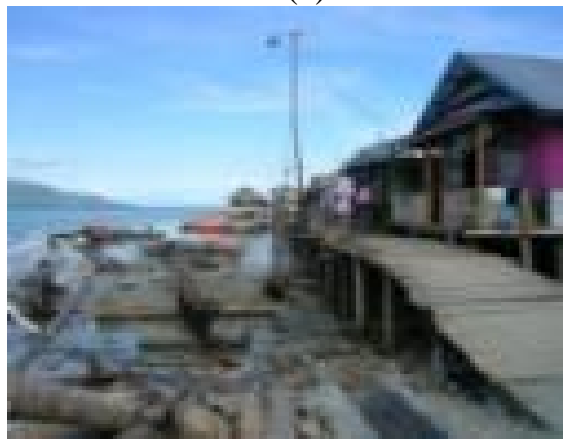

(c)

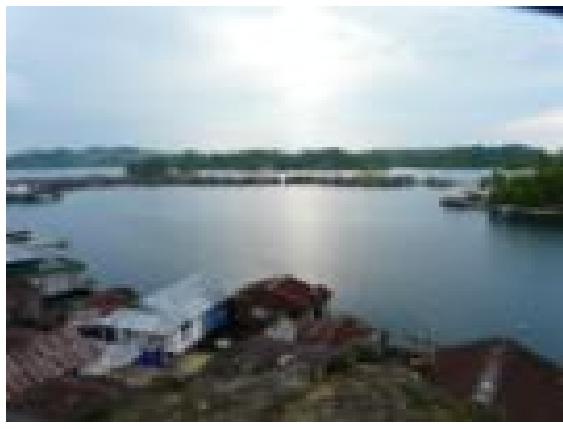

(b)

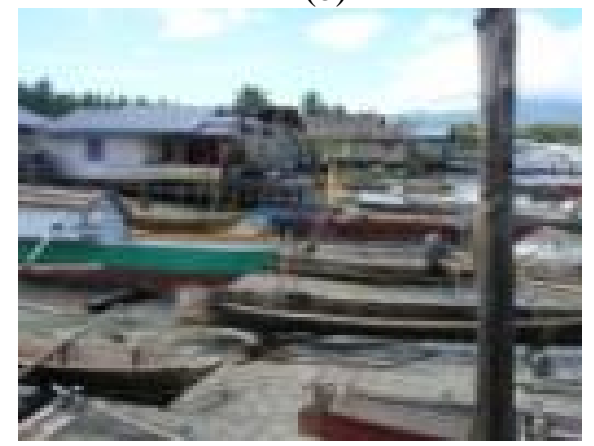

(d)

Gambar 4. Ruang permukiman yang terbentuk karena kondisi alam dan lingkungan. (a) Rumah tinggal mengelilingi bukit karang; (b) Pola/spasial lingkungan yang terbentuk pada permukiman desa/pulau Kabalutan; (c) Kelompok rumah tinggal menempati ruang pesisir dan laut, dan sebagai penghubung dibuat tetean (jembatan kayu); (d) Lahan pesisir pantai sebagai tempat menambat leppa/leppa-leppa (perahu/sampan). (Sumber : Analisis induksi berdasarkan data lapangan, 2012). 
lahan daratan, menyebabkan laut merupakan ruang bermain bagi anak-anak. Biasanya anak-anak bermain sambil mencari ikan, sehingga menggunakan sampan (perahu kecil atau leppaleppa). Masing-masing anak membawa sampan, jika telah memperoleh hasil yang diinginkan, anak-anak berenang sambil bercanda sebagaimana layaknya anak-anak. Kebiasaan ini dilakukan pada siang atau sore hari setelah pulang sekolah.

\section{Spasial terkait dengan Kondisi Fisik Ruang Permukiman}

Permukiman terdiri atas sekumpulan rumah yang dilengkapi dengan fasilitas lingkungan antara lain

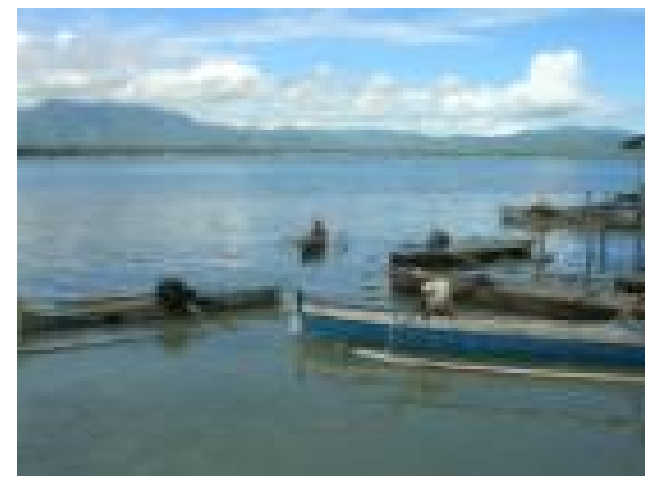

$\mathrm{a}$

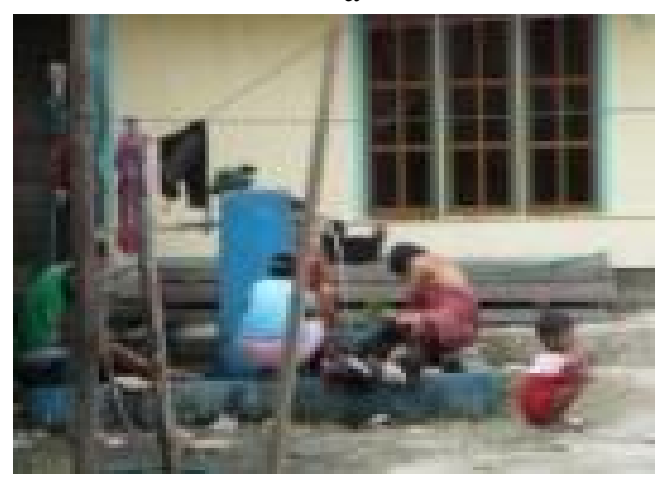

balai desa, mesjid atau mushollah, sekolah, puskesmas pembantu, tempat mandi cuci, bak air dan jalan atau tetean sebagai akses. Antar rumah terdapat ruang yang biasanya dimanfaatkan sebagai tempat memperbaiki sampan (perahu kecil), begitu pula pada ruang-ruang belakang rumah yang menghadap laut. Pada ruang yang lebih luas dimanfaatkan sebagai tempat membuat atau memperbaiki perahu dengan ukuran yang lebih besar.

Sebagian besar permukiman menempati lahan laut atau pesisir pantai, sehingga rumah tinggal berbentuk panggung menggunakan ketinggian tiang yang bervariasi sesuai kedalaman laut dan pasang-

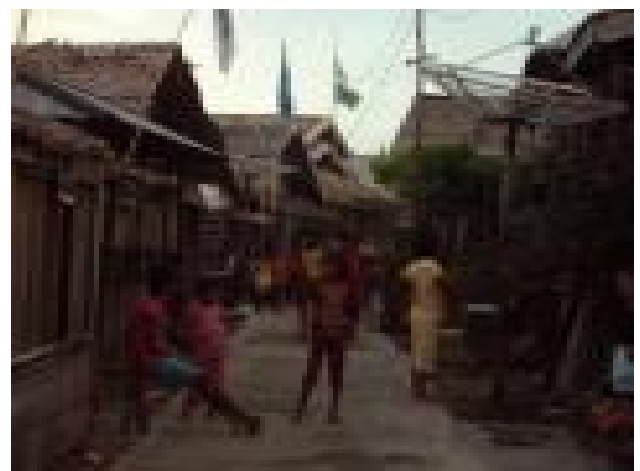

b

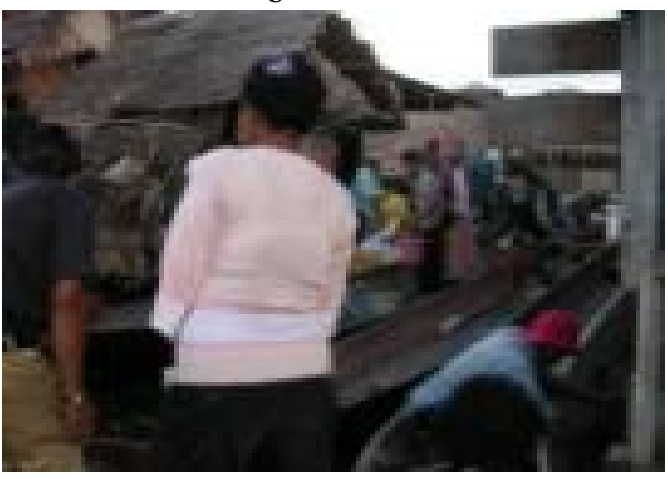

d

Gambar 5. Interaksi sosial yang dilakukan pemukim dan tempat yang digunakan : (a) Saat melaut, (b) di jalan, (c) tempat mandi cuci, dan (d) saat pasar pekan pada jalan dan tetean. (Sumber : Analisis induksi berdasarkan data lapangan, 2012).

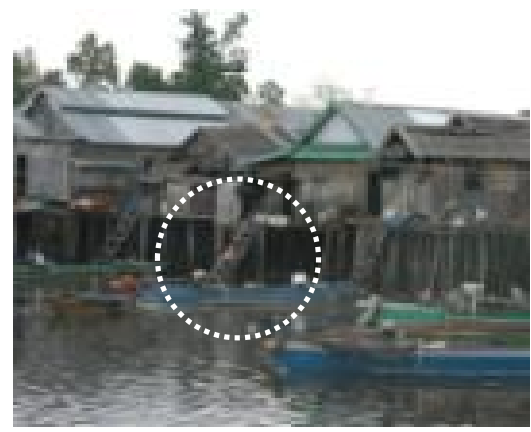

a

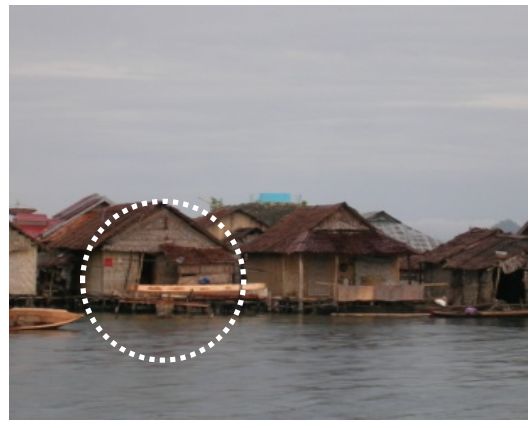

$\mathrm{b}$

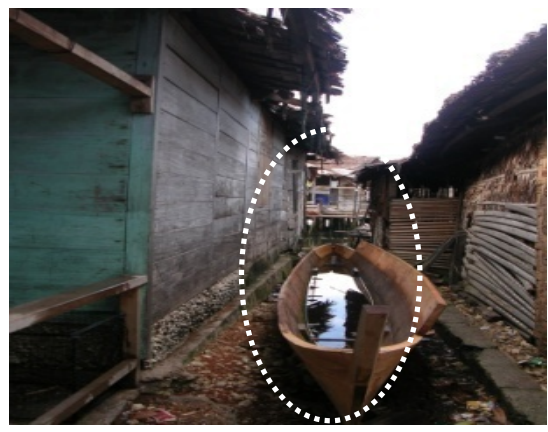

C

Gambar 6. Kondisi fisik ruang permukiman, tatambe (a) atau ruang belakang dan iga ruma' (b) atau ruang antar rumah sebagai akses dari rumah tinggal ke laut, membuat dan memperbaiki perahu. (Sumber : Analisis induksi berdasarkan data lapangan, 2012). 
surut air. Pada permukiman pulau, rumah tinggal mempunyai tiang setinggi $\pm 4-12 \mathrm{~m}$, sedang permukiman pesisir pantai mempunyai ketinggian lebih rendah yaitu \pm 3-5 m. Kolong rumah dimanfaatkan sebagai tempat pemeliharaan ikan (karamba), karena berhubungan langsung dengan air laut. Rumah tinggal dan laut dihubungkan oleh bagian belakang rumah tinggal yang disebut sebagai tatambe atau ruang tambahan. Ruang ini tidak saja sebagai akses ke laut juga sebagai ruang istirahat, tempat menyimpan hasil yang diperoleh selama melaut, alat penangkap ikan dan sumber daya laut lainnya

\section{KESIMPULAN}

Karakteristik spasial permukiman vernakular perairan, masih ditemui terutama pada permukiman pulau-pulau dan pesisir pantai di Sulawesi Tengah. Spasial permukiman membentuk pola melingkar satu arah mengelilingi daratan bukit karang atau linier melingkar satu dan dua arah dimana lalan (jalan) atau tetean (jembatan kayu) berfungsi sebagai akses, ruang publik dan pusat orientasi. Orientasi lain bersifat privat yaitu lao'/lau' (laut) sehingga ruang-ruang bagian belakang (tatambe) rumah tinggal menghadap ke laut. Pusat permukiman adalah mesjid atau musholah sebagai ruang sakral sekaligus ruang publik.

Pada kawasan pesisir, spasial permukiman membentuk garis linier sepanjang pantai, terdiri atas kelompok rumah tinggal, di mana tetean dan lalan (jalan) berfungsi sebagai akses ke daratan pantai. Lalan (jalan) merupakan ruang publik dan pusat orientasi secara horizontal, sedang lao'/lau' (laut) sebagai ruang kehidupan sekaligus pusat orientasi yang bersifat privat dan sakral.

\section{DAFTAR PUSTAKA}

Anonim, 2010. Rencana Tata Ruang Wilayah (RTRW) Kabupaten Tojo Una-Una Provinsi Sulawesi Tengah. Palu.

Doxiadis, C.A., 1957. Ekistics : An Introduction to The Science of Human Settlements. Hutchinson, London.
Hamundu, M., dan Manan, A., 2004. Extention and Communication in The Integrated Management Strategy for The Sustainable Development of Konawe Coastal Area Southeast Sulawesi Indonesia. Jurnal Manusia dan Lingkungan, 11(2):96-102.

Han, 1991. The Spatial Structure of the Traditional Settlements, a Study of The Clan Village in Korean Rural Area. Dessertation, Seoul National University, Seoul.

Haryadi dan Setiawan, B., 2006. Arsitektur Lingkungan dan Perilaku : Suatu Pengantar ke Teori, Metodologi dan Aplikasi. Direktorat Jenderal Pendidikan Tinggi dan Kebudayaan, Jakarta.

Hiller, B., dan Hanson, J., 1984. The Social Logic of Space. Cambridge University Press, Cambridge.

Hiller, B., 1989. The Architecture of The Urban Object. The Ekistics, 56(334/33):5-22.

Madanipour, A., 1996. Design of Urban Space : An Inquiry into Sosio-Spatial Process. John Wiley and Sons, Chichester.

Mentayani, I., dan Ikaputra, A., 2012. Menggali Makna Arsitektur Vernakular : Ranah, Unsur dan Aspek-aspek Vernakularitas. Lanting $1(2): 68-81$.

Oliver, P., (ed) 2006. Dwellings The House Across The World. Phaidon Press Limited, Oxford.

Rapoport, A., 1969. House Form and Culture. Prentice Hall, New Jersey.

Rejeki, V.G.S., Soewarno, N., Sudaryono, Subroto, W.Y.T., dan Putra, H.S.A., 2010. Prinsip Keruangan bagi Petani Ladang Tembakau di Lingkungan Desa Kapencar, Lereng Gunung Sindoro, Wonosobo. Jurnal Manusia dan Lingkungan, 17(1):46-56.

Setioko, B., Martini, T.W., dan Pandelaki, E.E., 2011. Conceptual Spatial Model of Coastal Settlement in Urbanizing Area. International Journal of Science and Research, 8(3):60-66.

Waterson, R., 1990. The Living House, An Antropology of Architecture in South East Asia. Oxford University Press, Singapore.

Yin, R.K., 2003. Case Study Research : Design and Methods. Sage Publisher, Newbury Park. 